\title{
Feeding a high-concentrate corn straw diet increased the release of endotoxin in the rumen and pro-inflammatory cytokines in the mammary gland of dairy cows
}

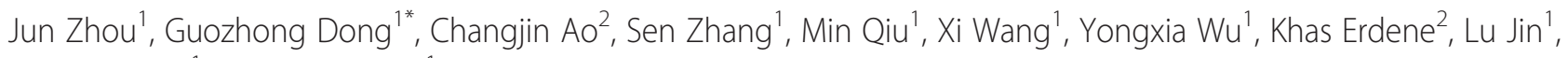
Chunlong Lei ${ }^{1}$ and Zhu Zhang ${ }^{1}$

\begin{abstract}
Background: The objective of this study was to investigate the effects of feeding a high-concentrate corn straw diet on the release of endotoxin in the rumen and the changes of pro-inflammatory cytokines in the mammary gland of dairy cows in comparison with a low-concentrate corn straw diet and a low-concentrate mixed forage diet. Thirty second-parity Chinese Holstein cows in mid-lactation with a body condition score of $2.86 \pm 0.29$, weighing $543 \pm 57 \mathrm{~kg}$ and producing $24.32 \pm 3.86 \mathrm{~kg}$ milk per day were randomly assigned to 1 of the 3 diets $(n=10$ per treatment): 1) low-concentrate mixed forage diet (LCF) with a concentrate to roughage ratio of $46: 54 ; 2$ ) high-concentrate corn straw diet (HCS) with a concentrate to roughage ratio of $65: 35 ; 3)$ low-concentrate corn straw diet (LCS) with the same concentrate to roughage ratio $(46: 54)$ as LCF. The experiment lasted 6 weeks, and samples were collected in the last week. Milk samples were analyzed for conventional components, rumen fluid samples were analyzed for $\mathrm{pH}$ and endotoxin, and mammary arterial and venous plasma samples were analyzed for concentrations of interleukin (IL)-1 $\beta$, IL-6, IL-8 and tumor necrosis factor alpha (TNF- $\alpha$ ).

Results: Concentrations of endotoxin in rumen fluid and feces of cows fed HCS were significantly higher than those of cows fed LCS and LCF. Feeding HCS increased the release of IL-1 $1 \beta, I L-6$ and IL-8 in the mammary gland compared with feeding LCS. Concentrations of cytokines (IL-1 $\beta$ and IL-8) in mammary venous plasma had a negative correlation with milk production efficiencies.

Conclusions: Results indicated that the high-concentrate corn straw diet increased the concentrations of endotoxin in rumen fluid and feces. Furthermore, feeding the high-concentrate corn straw diet stimulated the mammary gland to release more pro-inflammatory cytokines. The results suggest that feeding a high-concentrate corn straw diet induce a higher pro-inflammatory response in the mammary gland and thus may partly decrease the milk production efficiencies in dairy cows.
\end{abstract}

Keywords: Cytokine, Dairy cow, Endotoxin, Mammary gland

\footnotetext{
* Correspondence: gzdong@swu.edu.cn

${ }^{1}$ College of Animal Science and Technology, Southwest University, and Key Laboratory of Grass and Herbivores of Chongqing, 2 Tiansheng St., Beibei, Chongqing 400716, P.R. China

Full list of author information is available at the end of the article
} 


\section{Background}

Feeding dairy cows diets containing high proportions of concentrate to support high milk production is associated with the high incidence of subacute ruminal acidosis (SARA) [1-3]. SARA, a well recognized digestive disorder, poses a health threat to lactating dairy cows. The high rumen digestibility of most grains in concentrate mixtures increases the rumen's production of volatile fatty acids and causes a corresponding drop in rumen $\mathrm{pH}[1,4,5]$, which can result in alterations in the rumen environment, leading to changes in the composition of rumen microbiota [6,7] and accumulation of endotoxin (or lipopolysaccharide, LPS), a potentially harmful cell-wall component of all gram-negative bacteria [2,8,9]. LPS can translocate into the bloodstream across the epithelium barrier of the gastrointestinal tract wall $[4,10,11]$ and trigger inflammatory responses in cows [12-14]. The systemic inflammation caused by feeding cows diets rich in concentrate is associated with a variety of metabolic and immunologic alterations $[2,15]$. Furthermore, the systemic inflammation may reduce supply of milk component precursors for milk synthesis by repartitioning more nutrients for synthesis of immune molecules [3]. Nevertheless, the association between the rise of free endotoxin in rumen fluid during the feeding of diets high in concentrate and the local inflammation in the mammary gland in dairy cows has not yet been documented. In addition, in many countries, corn straw is frequently used in the diets of cows due to a lack of quality roughages. Consequently, the proportion of concentrate has to be raised to meet the nutrient requirements for lactation. Therefore, we hypothesized that increasing the concentrate proportion in a corn straw-based diet will result in increased release of endotoxin in the rumen, which may ultimately elicit a local inflammation in the mammary gland. Therefore, the objective of this study was to evaluate the effects of feeding a high-concentrate corn straw diet on the release of endotoxin in the rumen and pro-inflammatory cytokines in the mammary gland of dairy cows in comparison with a low-concentrate corn straw diet and a low-concentrate mixed quality forage diet.

\section{Methods}

\section{Animals, diets and experimental procedures}

Thirty second-parity Chinese Holstein cows in midlactation with a body condition score of $2.86 \pm 0.29$, averaging $543 \pm 57 \mathrm{~kg}$ of $\mathrm{BW}$ and producing $24.32 \pm$ $3.86 \mathrm{~kg}$ milk per day at the onset of the experiment, were randomly assigned to 1 of the 3 diets $(n=10$ per treatment): 1) low-concentrate mixed quality forage diet (LCF) with a concentrate to roughage ratio of $46: 54$, containing Chinese wildrye, alfalfa hay, and corn silage. This diet is commonly regarded as an ideal diet type for lactating cows and is served as control in the study; 2) high-concentrate corn straw diet (HCS) with a concentrate to roughage ratio of $65: 35$, containing corn straw as the only roughage; 3 ) low-concentrate corn straw diet (LCS) with the same concentrate to roughage ratio (46: 54) as LCF. The LCS diet also contained corn straw as the only roughage and is served as another control in the study. The concentrate of all the 3 diets consists of corn, soybean meal, whole cottonseed, $\mathrm{CaHPO}_{4}, \mathrm{NaCl}$ and premix. The ingredients and nutrient compositions of the experimental diets are presented in Table 1. Diets were mixed and offered as total mixed ration (TMR) twice daily (08:30 and 17:30 h). Orts were recorded and discarded before the next feeding each day and the amount of feed was adjusted to ensure a $5 \%$ feed residual. Cows were milked twice daily at 08:00 and 19:00 h, and milk yield was recorded electronically throughout the experiment period. The experiment lasted 6 weeks, and the last week was samples collection period. Cows were housed with playground and with free access to water. Cows in the experiment showed no clinical signs of

Table 1 Diet composition of the experimental diets

\begin{tabular}{|c|c|c|c|}
\hline \multirow[t]{2}{*}{ Item } & \multicolumn{3}{|l|}{$\underline{\text { Diet }}$} \\
\hline & LCF & HCS & LCS \\
\hline \multicolumn{4}{|l|}{ Ingredient (\% of dry matter) } \\
\hline Chinese wildrye & 3.7 & - & - \\
\hline Corn silage & 26.7 & - & - \\
\hline Alfalfa hay & 23.4 & - & - \\
\hline Corn straw & - & 35.0 & 53.8 \\
\hline Corn & 24.6 & 35.26 & 24.6 \\
\hline Soybean meal & 14.8 & 20.82 & 14.8 \\
\hline Whole cottonseed & 5.1 & 7.18 & 5.1 \\
\hline Dicalcium phosphate & 0.6 & 0.84 & 0.6 \\
\hline Salt & 0.5 & 0.5 & 0.5 \\
\hline Premix ${ }^{1}$ & 0.6 & 0.6 & 0.6 \\
\hline Total & 100 & 100 & 100 \\
\hline Concentrate to roughage ratio & $46: 54$ & $65: 35$ & $46: 54$ \\
\hline \multicolumn{4}{|c|}{ Nutrient composition (\% of dry matter) } \\
\hline Net energy (Mcal/kg) & 1.50 & 1.54 & 1.40 \\
\hline Crude protein & 16.8 & 16.9 & 13.9 \\
\hline Neutral detergent fiber & 37.6 & 34.4 & 46.0 \\
\hline Acid detergent fiber & 23.9 & 19.9 & 26.7 \\
\hline Non-fiber carbohydrate ${ }^{2}$ & 37.0 & 41.3 & 32.6 \\
\hline Ether extract & 3.4 & 3.2 & 2.5 \\
\hline Calcium & 0.50 & 0.45 & 0.42 \\
\hline Phosphorus & 0.38 & 0.41 & 0.35 \\
\hline \multicolumn{4}{|c|}{$\begin{array}{l}{ }^{1} \text { Contained Cu (as sulfate), 2,142 mg/kg; Mn (as sulfate), 15,428 mg/kg; Zn (as } \\
\text { sulfate), 15,428 mg/kg; Co (as chloride), } 28 \mathrm{mg} / \mathrm{kg} \text {; I (as iodate), } 231 \mathrm{mg} / \mathrm{kg} \text {; Se } \\
\text { (as selenite), } 57 \mathrm{mg} / \mathrm{kg} ; \text { vitamin A, 2,285,000 IU/kg; vitamin D, } 457,000 \mathrm{IU} / \mathrm{kg} ; \\
\text { and vitamin E, } 11,400 \mathrm{mg} / \mathrm{kg} . \\
{ }^{2} \text { Non-fiber carbohydrate = } 100 \text { - (\% Neutral detergent fiber +\% Crude } \\
\text { protein +\% Ether extract +\% Ash). }\end{array}$} \\
\hline
\end{tabular}


infectious diseases. This experiment was conducted at the Inner Mongolia Dairy United Technology Co., Ltd., Hohhot, China. All experimental procedures and the care of the animals were approved by the Inner Mongolia Agricultural University, and the ethical approval for conducting this study was also granted by the University. The methodology employed in this study was in accordance with the REFLECT guidelines (http://www. reflect-statement.org/statement/docs/reflectstatement checklist.pdf).

\section{Milk sampling and analysis and milk production efficiency calculation}

Milk samples ( $n=10$ per treatment) were obtained twice daily at 08:00 and 19:00 $\mathrm{h}$ in the last week of the experiment, and the daily samples were mixed with a ratio of $6: 4$ and analyzed for milk fat and protein contents by mid-infrared spectroscopy (MilkoScan FT120, Foss). Milk fat and protein yields were calculated from milk yield and milk fat and protein contents, and milk fat and protein synthesis efficiencies were calculated by dividing milk fat and protein yields with measured dry matter intake (DMI), respectively. Milk synthesis efficiency and 4\% fat corrected milk (FCM) synthesis efficiency were calculated by dividing milk yield and $4 \%$ FCM with DMI, respectively. DMI measures were obtained by multiplying the TMR intake by the dry matter content of the TMR.

\section{Rumen fluid and feces sampling and analysis}

Rumen fluid samples ( $n=10$ per treatment) were collected into two plastic containers 3 hours after the morning feeding on day 4 of the last week by an oral stomach tube equipped with a strainer and a syringe, as described by Shen et al. [16]. The initial $50 \mathrm{~mL}$ rumen fluid samples were discarded in order to avoid saliva contamination. The $\mathrm{pH}$ of rumen fluid was determined immediately by a mobile $\mathrm{pH}$ meter (Rex PHS-3E, INESA Scientific Instrument Co., Ltd). Fecal grab samples ( $n=10$ per treatment) were collected from the rectum on day 3 of the last week. The rumen fluid and feces samples were stored at $-20^{\circ} \mathrm{C}$ until being analyzed for LPS contents.

Concentrations of free LPS in the rumen fluid and feces were determined by the chromogenic end-point assay using the limulus amebocyte lysate (LAL) test reagent kit purchased from Xiamen Limulus Experiment Factory. The initial processing before LPS determination was as described by Khafipour et al. [14] with some modifications. In brief, rumen fluid samples were thawed quickly and centrifuged (Sigma 3-18 K, Sigma-Aldrich) at $6,000 \times g$ for $15 \mathrm{~min}$, and $1.5 \mathrm{~mL}$ of the supernatant was centrifuged again at $10,000 \times g$ for $30 \mathrm{~min}$. The supernatant was then passed through a disposable $0.22 \mu \mathrm{m}$ sterile, pyrogen-free filter (Millex, Millipore Corporation).
The filtrate was collected into a sterile, depyrogenated glass tube (previously heated at $250^{\circ} \mathrm{C}$ for $2 \mathrm{~h}$ ) and heated at $100^{\circ} \mathrm{C}$ for $30 \mathrm{~min}$. Samples were cooled at room temperature and diluted using pyrogen-free water and pyrogen-free test tubes until their LPS concentrations were in the range of 0.1 to 1 endotoxin units $(\mathrm{EU}) / \mathrm{mL}$ relative to the reference endotoxin (Escherichia coli O111:B4) provided by the manufacturer. In this analysis, rumen fluid samples were diluted 40,000-fold. Samples were analyzed according to the manual for the optical density at $545 \mathrm{~nm}$ on a microplate reader (Synergy H4, BioTek). Thawed feces samples were vortex mixed with an equal amount of physiological saline $(9 \mathrm{~g} / \mathrm{L} \mathrm{NaCl})$ for $15 \mathrm{~min}$. The mixture was then immediately processed for LPS assay using the same procedure as described above for rumen fluid samples.

\section{Blood sampling and analysis}

Blood samples ( $n=10$ per treatment) were obtained shortly before the morning feeding from the mammary (external pudendal) artery and the mammary vein, respectively, on day 6 and 7 of the last week of the trial. Cows were in a standing posture and restrained from movement during the whole process of blood sampling. In order to keep cows sedated, $20 \mathrm{~mL}$ procaine hydrochloride was injected into the muscles near the artery blood collection point, which was the triangle centre between the femoral joint and the hip joint. The operator then put one hand into cow's rectum against the external pudendal artery, and used the other hand to hold the sterile needle (18\#, $20 \mathrm{~cm}$ long) which was vertically penetrated into the fossa formed through the converging of the internal abdominal oblique muscle, the vastus lateralis muscle and the gluteus medius muscle, after shearing and disinfection. The mammary vein blood was collected at the site where the superficial abdominal vein can be easily located, after shearing and disinfection. Blood samples were collected into $10-\mathrm{mL}$ vacuum tubes (Shu Guang Jian Shi) containing heparin sodium anticoagulant and were stored in ice and centrifuged (Feige TDL-40B, Shanghai Anting Scientific Instrument Factory) within $10 \mathrm{~min}$ at $3,000 \times g$ and $4^{\circ} \mathrm{C}$ to harvest plasma. The plasma was divided into $1 \mathrm{~mL}$ aliquots, labeled immediately, and stored at $-20^{\circ} \mathrm{C}$ until being analyzed for cytokine concentrations.

The concentration of interleukin (IL)- $1 \beta$ in plasma was determined by a commercially available human IL$1 \beta$ ELISA kit (Invitrogen Corporation) according to the manufacturer's instructions, as described by Shuster et al. [17]. The specificity of the IL- $1 \beta$ activity was verified by blocking with recombinant human IL-1 receptor antagonist [17]. All samples including the standards were tested in duplicate, and the optical density values were read on an automatic microplate reader (ELx808; BioTek, Winooski, 
VT) at $450 \mathrm{~nm}$. The minimum detection limit of the assay was $3.9 \mathrm{pg} / \mathrm{mL}$. The concentration of IL-6 in plasma was quantified in duplicate by means of a commercially available human IL-6 ELISA kit (Invitrogen Corporation). The human IL-6 kit has been used as the assay standard for bovine IL-6 determination [17]. According to the manufacturer, the minimum detection limit of the assay was $7.8 \mathrm{pg} / \mathrm{mL}$ as defined by the linear range of standard curves. The samples were tested in duplicate, and the optical density at $450 \mathrm{~nm}$ was measured on a microplate reader (BioTek). Concentrations of IL-8 in plasma were determined with a commercially available human IL-8 ELISA kit (Invitrogen Corporation), which has been reported to cross-react with bovine IL-8 [17]. The measurable concentrations ranged from 15.6 to $1000 \mathrm{pg} / \mathrm{mL}$. Plasma samples were tested in duplicate, and the optical density at $450 \mathrm{~nm}$ was measured on a microplate reader (BioTek). Concentrations of tumor necrosis factor alpha (TNF- $\alpha$ ) in plasma were measured by a commercially available bovine TNF- $\alpha$ ELISA kit (Bethyl Laboratories, Inc.) according to the manufacturer's instructions. All samples including the standards were tested in duplicate, and the optical density values were read on a microplate reader (BioTek) at $450 \mathrm{~nm}$. The measurable concentrations ranged from 0.078 to $5 \mathrm{ng} / \mathrm{mL}$.

\section{Statistical analyses}

The general linear model (GLM) of SPSS (v.18) was used in the data analysis. The GLM included the random cow effect and the fixed effect of diets, and mean differences for all variables were separated and compared using Duncan multiple comparison procedure. Data are presented as means \pm standard deviation. Significance was declared at $P<0.05$ and a tendency was considered if
$0.05<P<0.10$. Statistical correlation was performed using GraphPad PRISM 5.0, and standard error, $P$-value, and $R^{2}$ were computed and used to evaluate the goodness of fit.

\section{Results}

DMI, milk yield, milk composition and milk production efficiencies

Data for DMI, milk yield, milk composition, and milk production efficiencies are shown in Table 2. Cows fed LCS had less DMI than cows fed LCF or HCS $(P<0.05)$, however, DMI was not different between LCF and HCS $(P>0.05)$. Milk yield and 4\% FCM were significantly different among the diets $(P<0.01)$. Cows fed LCF had higher milk yield and 4\% FCM than cows fed HCS, and cows fed LCS had the lowest milk yield and 4\% FCM. The contents of milk fat and protein in cows fed HCS and LCS were comparable $(P>0.05)$, which were lower than cows fed LCF $(P<0.05)$. Cows fed LCS had the lowest daily milk fat and protein yield $(P<0.05)$, whereas cows fed LCF had the highest daily milk fat and protein yield $(P<0.05)$. Cows fed LCF had higher milk production efficiencies than cows fed HCS or LCS, whereas the milk production efficiencies in cows fed HCS were not different from those in cows fed LCS.

\section{Ruminal $\mathrm{pH}$, and LPS in rumen fluid and feces}

There were no significant differences in ruminal $\mathrm{pH}$ between the LCF group and HCS group $(P>0.05)$, whereas the ruminal $\mathrm{pH}$ values of cows fed LCF and HCS were lower $(P<0.01)$ than those of cows fed LCS (Figure 1$)$. The highest LPS content of rumen fluid was observed in cows fed HCS $(P<0.01)$, and cows fed LCS and LCF had similar concentrations of ruminal LPS $(P>0.05)$ (Figure 2$)$.

Table 2 Effect of different diets on milk production performance in dairy cows

\begin{tabular}{|c|c|c|c|c|}
\hline \multirow[t]{2}{*}{ Items } & \multicolumn{3}{|l|}{ Diets $^{1}$} & \multirow[t]{2}{*}{$P$-value } \\
\hline & LCF & HCS & LCS & \\
\hline Dry matter intake $(\mathrm{kg} / \mathrm{d})$ & $20.74 \pm 1.87^{\mathrm{a}}$ & $20.33 \pm 2.23^{\mathrm{a}}$ & $18.52 \pm 0.97^{b}$ & 0.022 \\
\hline Milk yield (kg/d) & $25.64 \pm 4.71^{\mathrm{A}}$ & $21.75 \pm 3.89^{B}$ & $16.84 \pm 4.60^{C}$ & $<0.001$ \\
\hline $4 \%$ fat corrected milk (kg/d) & $26.27 \pm 3.99^{A}$ & $20.38 \pm 3.72^{B}$ & $16.74 \pm 5.00^{C}$ & $<0.001$ \\
\hline Milk fat content (\%) & $4.23 \pm 0.69^{a}$ & $3.58 \pm 0.42^{b}$ & $3.95 \pm 0.52^{b}$ & $<0.001$ \\
\hline Milk protein content (\%) & $3.18 \pm 0.19^{a}$ & $3.07 \pm 0.22^{b}$ & $3.04 \pm 0.13^{b}$ & 0.012 \\
\hline Milk fat yield (kg/d) & $1.07 \pm 0.18^{\mathrm{a}}$ & $0.78 \pm 0.16^{b}$ & $0.67 \pm 0.22^{c}$ & $<0.001$ \\
\hline Milk protein yield (kg/d) & $0.81 \pm 0.13^{\mathrm{A}}$ & $0.66 \pm 0.11^{B}$ & $0.51 \pm 0.14^{C}$ & $<0.001$ \\
\hline Milk synthesis efficiency (g/g) & $1.23 \pm 0.18^{\mathrm{a}}$ & $1.08 \pm 0.16^{\mathrm{ab}}$ & $0.98 \pm 0.22^{b}$ & 0.019 \\
\hline $4 \%$ fat corrected milk synthesis efficiency $(\mathrm{g} / \mathrm{g})$ & $1.23 \pm 0.18^{\mathrm{a}}$ & $1.01 \pm 0.14^{b}$ & $0.95 \pm 0.25^{b}$ & 0.011 \\
\hline Milk fat synthesis efficiency (\%) & $4.91 \pm 0.97^{\mathrm{a}}$ & $3.83 \pm 0.58^{b}$ & $3.74 \pm 1.16^{b}$ & 0.016 \\
\hline Milk protein synthesis efficiency (\%) & $3.86 \pm 0.42^{\mathrm{a}}$ & $3.30 \pm 0.38^{\mathrm{ab}}$ & $2.94 \pm 0.67^{b}$ & 0.001 \\
\hline
\end{tabular}

${ }^{1}$ LCF is low-concentrate mixed forage diet with a concentrate to roughage ratio of $46: 54$; HCS is high-concentrate corn straw diet with a concentrate to roughage ratio of $65: 35$; LCS is low-concentrate corn straw diet with the same concentrate to roughage ratio $(46: 54)$ as LCF.

A-C Means within a row differ $(P<0.01)$.

${ }^{\mathrm{a}-\mathrm{c}}$ Means within a row differ $(P<0.05)$. 


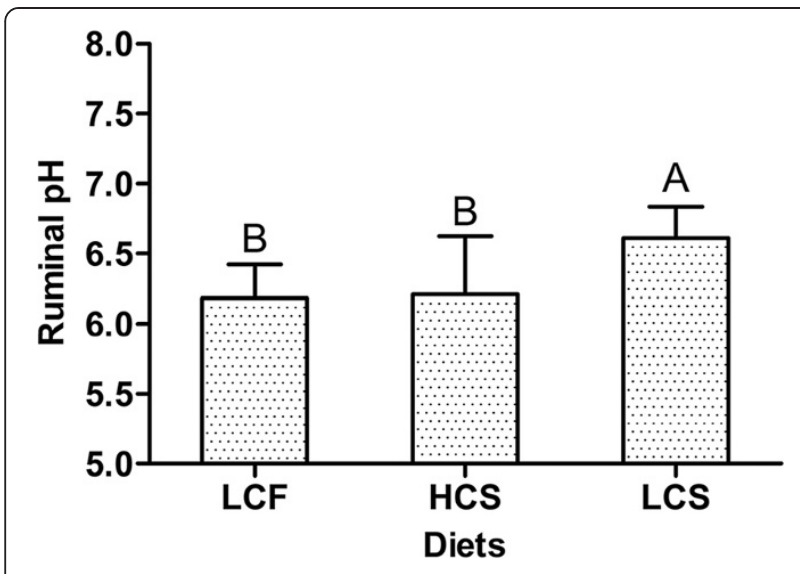

Figure 1 Effect of different diets on ruminal pH of dairy cows. LCF is low-concentrate mixed forage diet with a concentrate to roughage ratio of $46: 54$; HCS is high-concentrate corn straw diet with a concentrate to roughage ratio of $65: 35$; LCS is low-concentrate corn straw diet with the same concentrate to roughage ratio $(46: 54)$ as LCF. ${ }^{A-B}$ Means between treatments differ $(P<0.01)$.

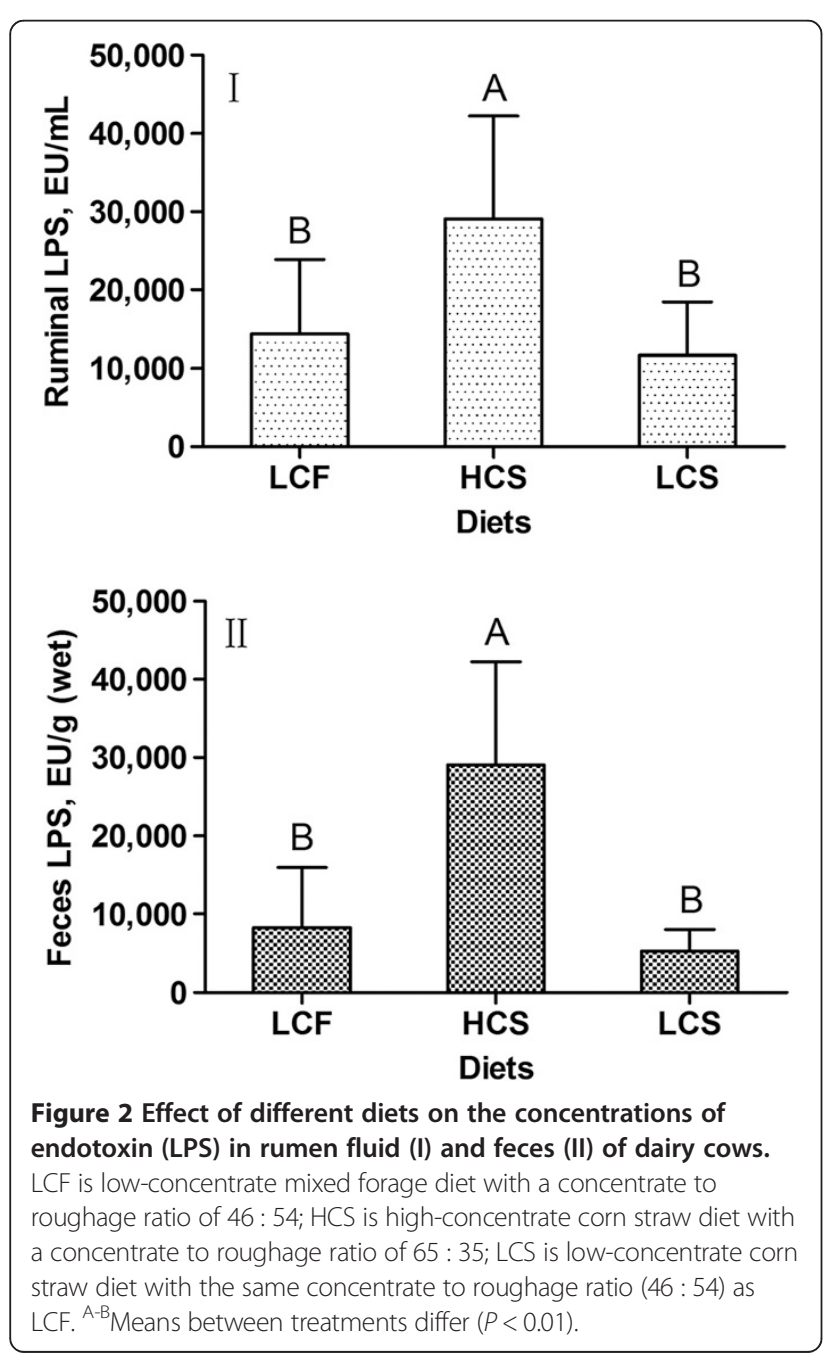

Both groups of cows fed LCF and LCS had lower concentrations of LPS in the feces compared with the group fed HCS $(P<0.01)$. There were no differences in fecal LPS contents between the groups of cows fed LCF and LCS $(P>0.05)$.

\section{Cytokines in mammary artery and vein blood}

No differences in mammary arterial plasma contents of IL-1 $\beta$, IL-6, IL- 8 and TNF- $\alpha$ among the experiment diets were observed $(P>0.05$; Table 3$)$. However, the concentrations of mammary venous plasma IL- $1 \beta$ and IL- 8 in the HCS group were higher than those of other groups $(P<0.05)$. The concentrations of mammary venous plasma IL-6 in the HCS group were higher than those of the LCS group $(P<0.05)$, but not different from those of the LCF group $(P>0.05)$. The mammary venous plasma TNF- $\alpha$ contents in the HCS group were numerically higher than those of the other two groups, but the data were highly variable and the difference did not attain statistical significance.

\section{Relationships between mammary venous plasma cytokines and milk production efficiencies}

The relationships between concentrations of mammary venous plasma IL-1 $\beta$, IL-6, IL-8 and milk production efficiencies (milk synthesis efficiency, 4\% FCM synthesis efficiency, milk fat synthesis efficiency, and milk protein synthesis efficiency) in dairy cows are presented in Figures 3, 4, 5, respectively. The increase in concentration of mammary venous plasma IL- $1 \beta$ was associated with a decline in milk production efficiencies (except milk protein synthesis efficiency; Figure 3). However, there were no significant relationships between mammary venous plasma IL-6 concentration and milk production efficiencies (Figure 4). The increase in concentration of mammary venous plasma IL-8 was also associated with a decline in milk production efficiencies (except milk synthesis efficiency; Figure 5).

\section{Discussion}

Khafipour et al. [14] reported that DMI, milk yield, and milk fat percentage were reduced when they used pellet containing $50 \%$ wheat and $50 \%$ barley to replace $21 \%$ of the dry matter (DM) of the control diet with a concentrate to roughage ratio of 50:50. Results of our study showed that milk yield, $4 \%$ FCM, milk fat percentage, milk protein percentage and milk production efficiencies were lower in cows fed HCS than those in cows fed LCF, although the nutrient levels were similar between these two diets. The reduction in milk production performance in cows fed HCS may be due to the adverse effects resulting from the increased concentrate proportion $[3,10,11]$ as well as the low quality of corn straw. As demonstrated in this study, feeding a high-concentrate diet induced more 
Table 3 Effect of different diets on cytokine contents in mammary arterial and venous plasma of dairy cows

\begin{tabular}{|c|c|c|c|c|c|}
\hline \multirow[t]{2}{*}{ Items $^{1}$} & & \multicolumn{3}{|l|}{ Diets $^{2}$} & \multirow[t]{2}{*}{$P$-value } \\
\hline & & $\overline{\mathrm{LCF}}$ & $\mathrm{HCS}$ & LCS & \\
\hline \multirow[t]{4}{*}{ Artery } & $\| \mathrm{L}-1 \beta(\mathrm{pg} / \mathrm{mL})$ & $217.12 \pm 32.93$ & $226.08 \pm 32.20$ & $221.05 \pm 27.03$ & 0.407 \\
\hline & IL-6 (pg/mL) & $63.43 \pm 20.96$ & $67.09 \pm 20.03$ & $64.35 \pm 19.39$ & 0.683 \\
\hline & IL-8 (pg/mL) & $77.82 \pm 17.39$ & $91.12 \pm 17.96$ & $81.97 \pm 17.18$ & 0.273 \\
\hline & TNF-a (ng/mL) & $0.55 \pm 0.85$ & $0.72 \pm 0.99$ & $0.32 \pm 0.38$ & 0.546 \\
\hline \multirow[t]{4}{*}{ Vein } & $\| \mathrm{L}-1 \beta(\mathrm{pg} / \mathrm{mL})$ & $211.42 \pm 25.45^{b}$ & $246.99 \pm 36.62^{\mathrm{a}}$ & $210.98 \pm 20.27^{b}$ & 0.030 \\
\hline & IL-6 (pg/mL) & $86.10 \pm 7.12^{b}$ & $82.73 \pm 9.08^{b}$ & $74.77 \pm 9.22^{a}$ & 0.050 \\
\hline & IL-8 (pg/mL) & $76.26 \pm 11.45^{B}$ & $98.58 \pm 11.71^{\mathrm{A}}$ & $77.34 \pm 9.52^{B}$ & 0.001 \\
\hline & TNF-a (ng/mL) & $0.55 \pm 0.88$ & $0.82 \pm 1.10$ & $0.38 \pm 0.44$ & 0.323 \\
\hline
\end{tabular}

${ }^{1} \mathrm{IL}=$ interleukin, $\mathrm{TNF}=$ tumor necrosis factor.

${ }^{2} \mathrm{LCF}$ is low-concentrate mixed forage diet with a concentrate to roughage ratio of $46: 54$; $\mathrm{HCS}$ is high-concentrate corn straw diet with a concentrate to roughage ratio of $65: 35$; LCS is low-concentrate corn straw diet with the same concentrate to roughage ratio (46:54) as LCF.

A-B Means within a row differ $(P<0.01)$.

${ }^{a-b}$ Means within a row differ $(P<0.05)$.

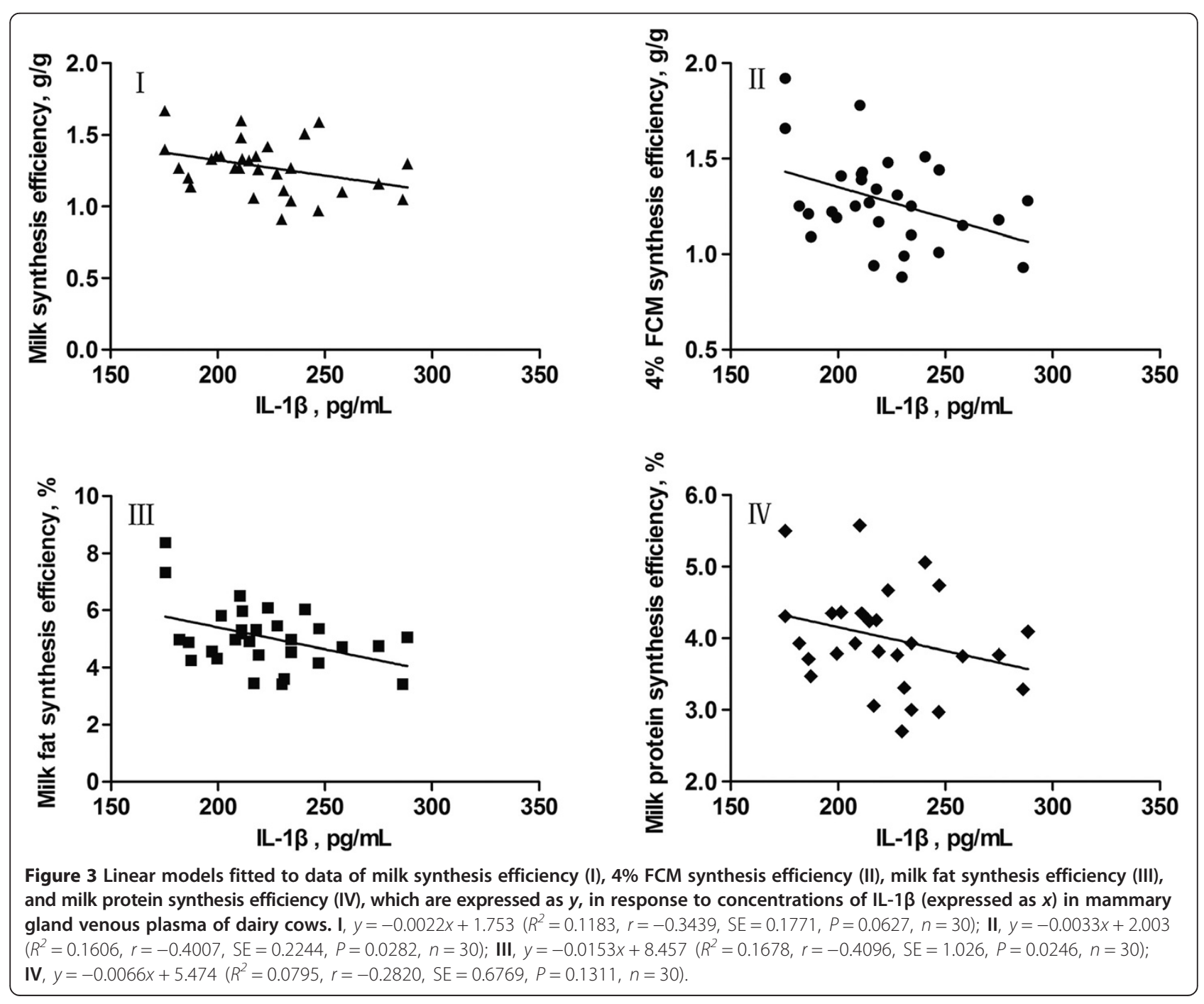




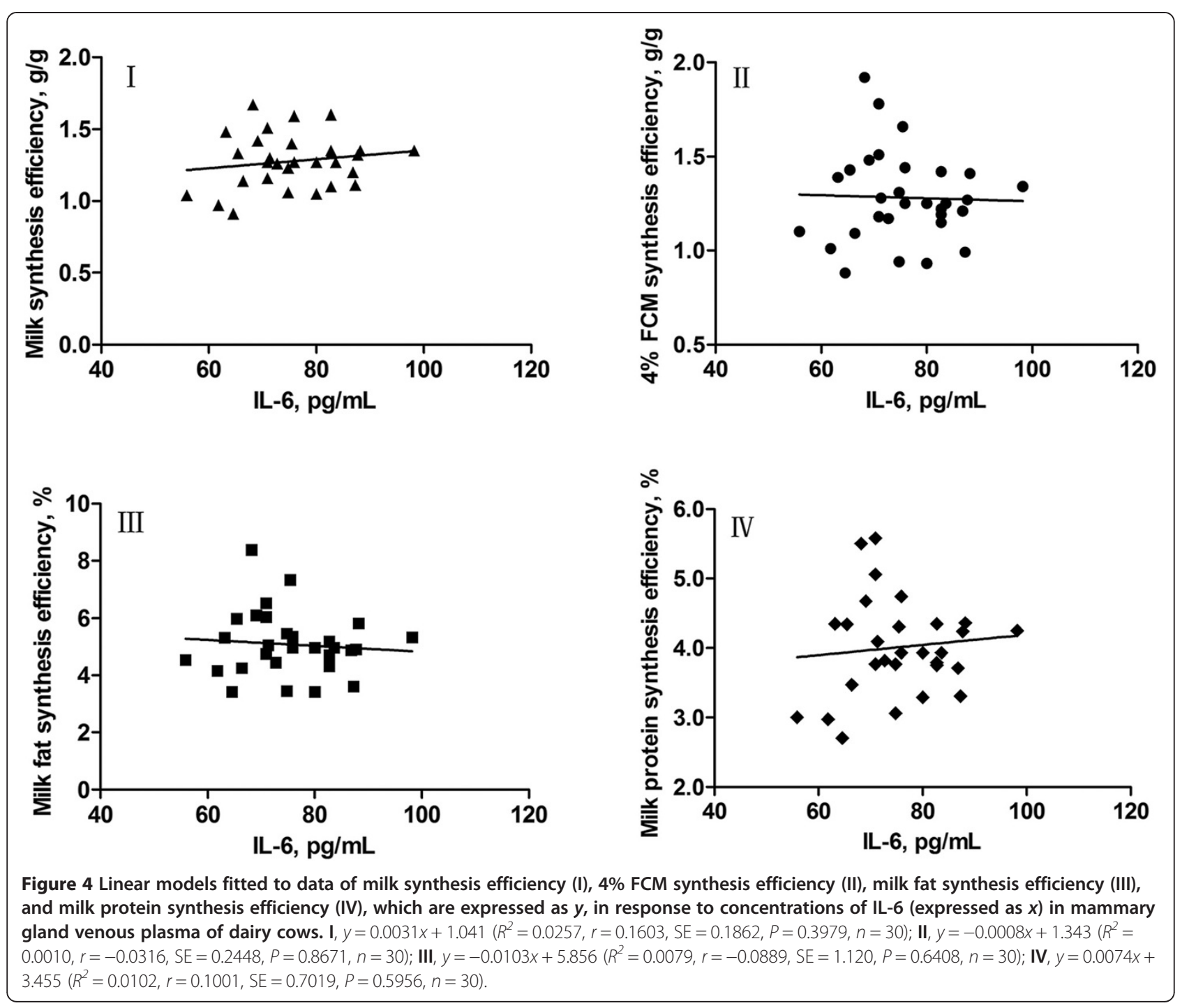

LPS in the rumen, which can elicit systemic inflammatory response and local inflammatory response in the udder after translocation of LPS into blood [3]. Under the circumstances, nutrients will be directed to support proinflammatory events. The redirection or repartition of nutrient use in addition to a low nutrient supply due to the low quality of corn straw will decrease nutrient availability for milk synthesis. Furthermore, the LPS entering the mammary tissue may directly exert harmful effects on the mammary epithelial cells, and those effects include reducing proliferation of the epithelial cells, increasing cell apoptosis, and suppressing the activity of key enzymes in milk component synthesis such as fatty acid synthetase, acetyl-CoA carboxylase and lipoprotein lipase [3].

Results of this study also showed that DMI, milk yield, $4 \%$ FCM, milk fat percentage, milk protein percentage and milk production efficiencies were lower in cows fed LCS than those in cows fed LCF. The poor milk production performance in cows fed LCS could be attributed to the low DMI and low dietary energy and protein levels in comparison with cows fed LCF. In this study, cows fed HCS had higher DMI, milk yield, and 4\% FCM than cows fed LCS, which could be attributed to the higher dietary energy and protein levels in the HCS diet due to the increased concentrate proportion and the reduced straw proportion. However, the milk production efficiencies between the two groups of cows were not different and the reason may be that the HCS diet induced more ruminal LPS, the adverse effects of which compromised the milk production efficiencies.

A large number of studies indicate feeding cows diets high in concentrate is associated with low rumen $\mathrm{pH}$ $[14,18]$. Accordingly, in our study the ruminal $\mathrm{pH}$ of cows fed the high-concentrate diet (HCS) was significantly lower than that of cows fed the low-concentrate diet (LCS). Interestingly, the ruminal $\mathrm{pH}$ in cows fed the low- 

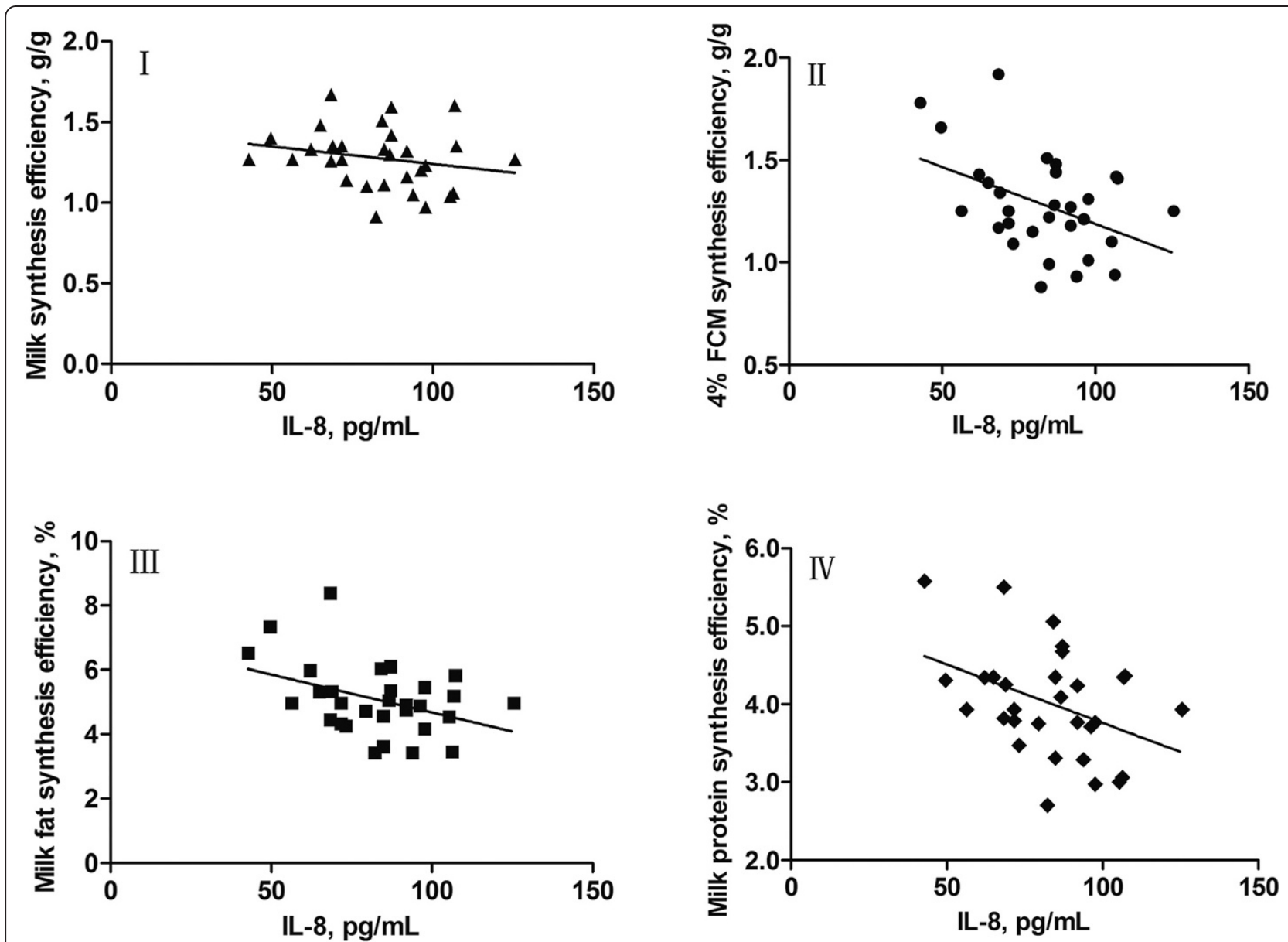

Figure 5 Linear models fitted to data of milk synthesis efficiency (I), 4\% FCM synthesis efficiency (II), milk fat synthesis efficiency (III), and milk protein synthesis efficiency (IV), which are expressed as $y$, in response to concentrations of IL-8 (expressed as $x$ ) in mammary gland venous plasma of dairy cows. $\mathbf{I}, y=-0.0022 x+1.457\left(R^{2}=0.0477, r=-0.2184, \mathrm{SE}=0.1840, P=0.2462, n=30\right) ; \mathbf{I I}, y=-0.0056 x+1.746$ $\left(R^{2}=0.1879, r=-0.4335, \mathrm{SE}=0.2207, P=0.0167, n=30\right) ; \mathrm{III}, y=-0.0236 x+7.037\left(R^{2}=0.1595, r=-0.3394, \mathrm{SE}=1.031, P=0.0288, n=30\right)$; IV, $y=-0.0149 x+5.255\left(R^{2}=0.1622, r=-0.4027, \mathrm{SE}=0.6458, P=0.0273, n=30\right)$.

concentrate diet (LCF) was not different from that in cows fed the high-concentrate diet (HCS). In this study, the LCF diet contained 26.7\% (DM basis) of corn silage that was rich in lactic acid, which may serve as an explanation for the low ruminal $\mathrm{pH}$ observed for this lowconcentrate diet.

Our results showed that feeding dairy cows the highconcentrate diet (HCS) was associated with increased concentrations of LPS in the rumen fluid and feces. Cows receiving $65 \%$ concentrate (HCS) had higher amounts of free LPS in rumen fluid and feces compared with cows receiving $46 \%$ concentrate (LCS or LCF). As expected, no differences in the amount of free LPS in rumen fluid and feces between the groups fed LCF and LCS were obtained. Our findings are consistent with previous studies demonstrating enhanced content of LPS in rumen fluid from feedlot steers or dairy cows fed diets containing high proportions of grain $[19,20]$. Emmanuel et al. [12] reported a 10 -fold increase in the concentration of LPS in rumen fluid of cows when dietary barley grain increased from $15 \%$ to $45 \%$. Another study reported the concentration of LPS in rumen fluid increased about 3-fold when steers were fed a $61 \%$ concentrate diet compared with those fed an all-forage diet [21]. Results of this study also showed the concentration of LPS in feces increased with increasing the diet concentrate. This is in agreement with the study by Li et al. [22] who reported the grain based SARA challenge increased LPS in feces from 12,832 to $118,522 \mathrm{EU} / \mathrm{g}$.

LPS produced in the gastrointestinal tract can be translocated into the bloodstream, thus the concentration of peripheral blood LPS increases [14,23]. Khafipour et al. [14] reported that the concentrations of both ruminal and blood LPS increased, when they replaced $21 \%$ of the DM of the control diet with a concentrate to roughage ratio of 50:50 with pellet containing 50\% ground wheat and 50\% ground barley. It was also observed in other studies that SARA led to a rise of blood LPS concentrations [24,25]. 
Our study is the first to report the concentrations of pro-inflammatory cytokines in mammary arterial and venous plasma. Results of this study demonstrated that the release of cytokines (IL-1, IL-6, IL- 8 and perhaps TNF- $\alpha$ ) increased in the mammary gland when cows fed the high-concentrate diet (HCS) compared with cows fed the low-concentrate diet (LCS). The increases in the release of cytokines in the mammary gland provide evidence of LPS translocation into this tissue and activated local inflammation in the tissue. A study by Lee et al. [26] also showed that the concentrations of IL-8 and TNF- $\alpha$ in milk increased immediately after administering healthy cows with $100 \mu \mathrm{g}$ LPS. IL- 8 is one of the most important chemokines for recruitment of neutrophils to inflammatory sites [27]. TNF- $\alpha$ is stimulated and secreted after activation of nuclear factor- $\mathrm{kB}$ pathway via toll-like receptors [28], and causes pathophysiological events similar to that of endotoxaemia or septic shock [29]. IL-1 $\beta$ is produced as a pro-cytokine upon initial stimulation of immune cells via toll-like receptors [30]. IL-6 is a complex cytokine in the roles of enhancing or limiting the immune response [30]. In our study, the high content of IL- 6 detected in cows fed LCF may be attributed to that IL-6 is a duplicitous cytokine playing both pro- and anti-inflammatory roles.

The negative relationships between the concentrations of mammary venous plasma IL- $1 \beta$ and IL- 8 and milk production efficiencies in dairy cows were demonstrated in our study. The adverse effects of LPS on lactation were detailed in a review by Dong et al. [3]. The reduced milk production efficiencies in dairy cows may be partly attributed to the local inflammation in the mammary tissue induced by LPS translocated into the body from the digestive tract. As a result of the local inflammation, more nutrients or precursors of milk components will be directed to support immune processes, resulting in less precursors being used for synthesizing milk components. LPS may also exert harmful effects on the mammary epithelial cells [31,32] and suppress the activity of enzymes involved in milk component synthesis [33-35].

\section{Conclusions}

Feeding dairy cows a corn straw-based diet with a high proportion of concentrate was associated with higher concentrations of LPS in ruminal fluid and feces. Furthermore, feeding the high-concentrate corn straw diet increased pro-inflammatory cytokines in the mammary venous blood, and the concentrations of cytokines (IL$1 \beta$ and IL-8) in mammary venous plasma had a negative correlation with milk production efficiencies. The results suggest that feeding a high-concentrate corn straw diet induce a higher pro-inflammatory response in the mammary gland and thus may partly decrease the milk production efficiencies in dairy cows.

\section{Competing interests}

None of the authors has any financial or personal competing interests that could inappropriately influence or bias the content of the paper.

\section{Authors' contributions}

$J Z$ and GD conceived the overall idea of this study and wrote the manuscript. CA and KE contributed to animal experiment design. SZ, MQ, $X W, Y W, L J, C L$ and ZZ participated in animal experiment and samples analysis. All authors read and approved the manuscript.

\section{Acknowledgments}

The study was supported by funds from the National Key Basic Research Program of China (No. 2011CB100803). We gratefully thank the teachers and students of the animal nutrition and feed science group of Southwest University for their help. We also acknowledge the "Dairy 973" team of Inner Mongolia Agricultural University for their assistance in conducting this experiment.

\section{Author details}

${ }^{1}$ College of Animal Science and Technology, Southwest University, and Key Laboratory of Grass and Herbivores of Chongqing, 2 Tiansheng St., Beibei, Chongqing 400716, P.R. China. ${ }^{2}$ College of Animal Science, Inner Mongolia Agricultural University, 306 Zhaowuda St., Hohhot, Inner Mongolia 010018, P.R. China.

Received: 5 March 2014 Accepted: 21 July 2014

Published: 1 August 2014

\section{References}

1. Nocek JE: Bovine acidosis: implications on laminitis. J Dairy Sci 1997, 80:1005-1028.

2. Ametaj BN, Emmanuel DGV, Zebeli Q, Dunn SM: Feeding high proportions of barley grain in a total mixed ration perturbs diurnal patterns of plasma metabolites in lactating dairy cows. J Dairy Sci 2009, 92:1084-1091.

3. Dong GZ, Liu SM, Wu YX, Lei CL, Zhou J, Zhang S: Diet-induced bacterial immunogens in the gastrointestinal tract of dairy cows: Impacts on immunity and metabolism. Acta Vet Scand 2011, 53:48.

4. Emmanuel DGV, Madsen KL, Churchill TA, Dunn SM, Ametaj BN: Acidosis and lipopolysaccharide from Escherichia coli B:055 cause hyperpermeability of rumen and colon tissues. J Dairy Sci 2007, 90:5552-5557.

5. Iqbal S, Zebeli Q, Mazzolari A, Bertoni G, Dunn SM, Yang WZ, Ametaj BN: Feeding barley grain steeped in lactic acid modulates rumen fermentation patterns and increases milk fat content in dairy cows. J Dairy Sci 2009, 92:6023-6032.

6. Keunen JE, Plaizier JC, Kyriazakis L, Duffield TF, Widowski TM, Lindinger MI, McBride BW: Effects of a subacute ruminal acidosis model on the diet selection of dairy cows. J Dairy Sci 2002, 85:3304-3313.

7. Zebeli Q, Dunn SM, Ametaj BN: Perturbations of plasma metabolites correlated with the rise of rumen endotoxin in dairy cows fed diets rich in easily degradable carbohydrates. J Dairy Sci 2011, 94:2374-2382.

8. Ametaj BN, Bradford BJ, Bobe G, Nafikov RA, Lu Y, Young JW, Beitz DC: Strong relationships between mediators of the acute phase response and fatty liver in dairy cows. Can J Anim Sci 2005, 85:165-175.

9. Zebeli Q, Ametaj BN: Relationships between rumen lipopolysaccharide and mediators of inflammatory response with milk fat production and efficiency in dairy cows. J Dairy Sci 2009, 92:3800-3809.

10. Plaizier JC, Krause DO, Gozho GN, McBride BW: Subacute ruminal acidosis in dairy cows: The physiological causes, incidence and consequences. Vet J 2008, 176:21-31.

11. Plaizier JC, Khafipour E, Li S, Gozho GN, Krause DO: Subacute ruminal acidosis (SARA), endotoxins and health consequences. Anim Feed Sci Tech 2012, 172:9-21.

12. Emmanuel DGV, Dunn SM, Ametaj BN: Feeding high proportions of barley grain stimulates an inflammatory response in dairy cows. J Dairy Sci 2008, 91:606-614.

13. Ametaj BN, Koenig KM, Dunn SM, Yang WZ, Zebeli Q, Beauchemin KA: Backgrounding and finishing diets are associated with inflammatory responses in feedlot steers. J Dairy Sci 2009, 87:1314-1320.

14. Khafipour E, Krause DO, Plaizier JC: A grain-based subacute ruminal acidosis challenge causes translocation of lipopolysaccharide and triggers inflammation. J Dairy Sci 2009, 92:1060-1070. 
15. Andersen $\mathrm{PH}$, Hesselholt M, Jarløv N: Endotoxin and arachidonic acid metabolites in portal, hepatic and arterial blood of cattle with acute ruminal acidosis. Acta Vet Scand 1994, 35:223-234.

16. Shen JS, Chai Z, Song L, Liu JX, Wu YM: Insertion depth of oral stomach tubes may affect the fermentation parameters of ruminal fluid collected in dairy cows. J Dairy Sci 2012, 95:5978-5984.

17. Shuster DE, Kehrli ME, Rainard P, Paape MJ: Complement fragment C5a and inflammatory cytokines in neutrophil recruitment during intramammary infection with Esche-richia coli. Infect Immun 1997 65:3286-3292

18. Gozho GN, Krause DO, Plaizier JC: Ruminal lipopolysaccharide concentration and inflammatory response during grain-induced subacute ruminal acidosis in dairy cows. J Dairy Sci 2007, 90:856-866.

19. Nagaraja TG, Bartley EE, Fina LR, Anthony HD: Relationship of rumen gram-negative bacteria and free endotoxin to lactic acidosis in cattle. J Anim Sci 1978, 47:1329-1336.

20. Andersen PH: Bovine endotoxicosis: Some aspects of relevance to production diseases. Acta Vet Scand Supp/ 2003, 98:141-155.

21. Gozho GN, Krause DO, Plaizier JC: Rumen lipopolysaccharide and inflammation during grain adaptation and sub-acute ruminal acidosis in steers. J Dairy Sci 2006, 89:4404-4413.

22. Li S, Khafipour E, Krause DO, Kroeker A, Rodriguez-Lecompte JC, Gozho GN, Plaizier JC: Effects of subacute ruminal acidosis challenges on fermentation and endotoxins in the rumen and hindgut of dairy cows. J Dairy Sci 2012, 95:294-303.

23. Dougherty RW, Coburn KS, Cook HM, Allison MJ: A preliminary study of the appearance of endotoxin in the circulatory system of sheep and cattle after induced grain engorgement. Am J Vet Res 1975, 36:831-832.

24. Chen J, Chen JX, Zou DD, Xu KW, Dai XT: Changes in physiological and biochemical parameters in blood and the rumen fluid of dairy cattle suffering laminitis in Nanjing. Ch J Vet Med 1990, 6:19-20.

25. Lu TS, Chen J, Tang AF, Xu KW: A study on manipulating blood histamine and endotoxin levels and improving milk production by using rumen buffers in dairy cattle. Ch Dairy Cattle 1992, 6:45-47.

26. Lee JW, Paape MJ, Elsasser TH, Zhao X: Elevated milk soluble CD14 in bovine mammary glands challenged with Escherichia coli lipopolysaccharide. J Dairy Sci 2003, 86:2382-2389.

27. Candel-Marti ME, Flichy-Fernandez AJ, Alegre-Domingo T, Ata-Ali J, Penarrocha-Diago MA: Interleukins IL-6, IL-8, IL-10, IL-12 and periimplant disease. An update. Med Oral Patol Oral Cir Bucal 2011, 16:e518-e521.

28. Bryant CE, Spring DR, Gangloff M, Gay NJ: The molecular basis of the host response to lipopolysaccharide. Nature Reviews. Nat Rev Microbiol 2010, 8:8-14.

29. Nakajima Y, Mikami O, Yoshioka M, Motoi Y: Elevated levels of tumor necrosis factor-a (TNF-a) and interleukin-6 (IL-6) activities in the sera and milk of cows with naturally occurring coliform mastitis. Res Vet Sci 1997, 62:297-298

30. Galvão KN, Felippe MJB, Brittin SB, Sper R, Fraga M, Galvão JS, Caixeta L, Guard CL, Ricci A, Gilbert RO: Evaluation of cytokine expression by blood monocytes of lactating Holstein cows with or without postpartum uterine disease. Theriogenology 2012, 77:356-372.

31. Ledbetter TK, Paape MJ, Douglas LW: Cytotoxic effects of peroxynitrite, polymorphonuclear neutrophils, free radical scavengers, inhibitors of myeloperoxidase, and inhibitors of nitric oxide synthase on bovine mammary secretory epithelial cells. Am J Vet Res 2001, 62:286-293.

32. Boulanger $V$, Zhao $X$, Lacasse $P$ : Protective effects of melatonin and catalase in bovine neutrophil-induced model of mammary cell damage. J Dairy Sci 2002, 85:562-569.

33. Pekala PH, Kawakami M, Angus CW, Lane MD, Cerami A: Selective inhibition of synthesis of enzymes for de novo fatty acid biosynthesis by an endotoxin-induced mediator from exudates cells. Proc Natl Acad Sci U S A 1983, 80:2743-2747.
34. López-Soriano FJ, Williamson DH: Acute effects of endotoxin (lipopolysaccharide) on tissue lipid metabolism in the lactating rat. The role of delivery of intestinal glucose. Mol Cell Biochem 1994, 141:113-120.

35. Khovidhunkit W, Kim MS, Memon RA, Shigenaga JK, Moser AH, Feingold KR, Grunfeld C: Effects of infection and inflammation on lipid and lipoprotein metabolism: Mechanisms and consequences to the host. J Lipid Res 2004, 45:1169-1196.

doi:10.1186/s12917-014-0172-0

Cite this article as: Zhou et al:: Feeding a high-concentrate corn straw diet increased the release of endotoxin in the rumen and pro-inflammatory cytokines in the mammary gland of dairy cows. BMC Veterinary Research 2014 10:172.

\section{Submit your next manuscript to BioMed Central and take full advantage of:}

- Convenient online submission

- Thorough peer review

- No space constraints or color figure charges

- Immediate publication on acceptance

- Inclusion in PubMed, CAS, Scopus and Google Scholar

- Research which is freely available for redistribution

Submit your manuscript at www.biomedcentral.com/submit
C Biomed Central 